\title{
Exoproteolytic activity in an Atlantic pond (France): estimates of in situ activity
}

\author{
C. Crottereau*, D. Delmas \\ Centre de Recherches en Ecologie et Aquaculture de L'Houmeau, CNRS-IFREMER, BP 5, F-17137 L'Houmeau, France
}

\begin{abstract}
In order to estimate in situ bacterial exoproteolysis and its contribution to bacterial secondary production (BSP), we studied microbial activities (BSP and kinetics of exoproteolytic activity) in relation to dissolved combined amino acids (DCAA) during the survey of an Atlantic marine pond. In this pond, high concentrations of DCAA (mean $=4.27 \mu \mathrm{M}$ ), probably generated by zooplankton grazing, allowed large bacterial biomass development and high production (max $=10^{11}$ cells $1^{-1}$ and $18.8 \times$ $10^{9}$ cells $\mathrm{l}^{-1} \mathrm{~d}^{-1}$ respectively). Exoproteolytic enzyme activity (mean $V_{\mathrm{m}}=55.9 \mu \mathrm{M} \mathrm{d}^{-1}$ ) was tightly coupled to bacterial production, suggesting that protein utilization was essential for bacterial growth. Calculation, according to the Michaelis-Menten equation, of the dissolved protein in situ hydrolysis rates using the kinetic parameters $\left(V_{\mathrm{m}}\right.$ and $\left.K_{\mathrm{m}}\right)$ and the ambient concentration of DCAA proved to be a better estimation of the actual rate of hydrolytic activity than the potential activity based on $V_{\mathrm{m}}$ only. The rates found with this calculation agreed with those obtained from different environments with other methods (DCAA and labelled proteins uptake). Furthermore, our estimates of in situ proteolysis were consistent with BSP (nitrogen fluxes originating from dissolved protein hydrolysis averaging $56 \%$ of the $\mathrm{N}$ bacterial production), and as a result, these estimates seem to provide a realistic estimation of the actual dissolved protein hydrolysis rates.
\end{abstract}

KEY WORDS: Bacterioplankton - In situ exoproteolytic hydrolysis rate $\cdot$ Kinetic parameters D DAA Marine pond

\section{INTRODUCTION}

In aquatic environments, most dissolved organic matter is derived from phytoplankton exudation (Larsson \& Hagström 1982, Baines \& Pace 1991), grazing and cellular lysis (Jumars et al. 1989) and dissolution of particulate organic matter. Dissolved proteins make up the largest identified pool of dissolved organic nitrogen (DON) (Sharp 1983, Williams 1986) and cannot be assimilated directly by bacteria (Chróst 1990). DON readily used by bacteria appears to be in very low concentrations (Chróst et al. 1989, Münster \& Chróst 1990) and may not be sufficient to support high bacterial biomass and production (Chróst 1992). This apparent bacterial paradox' could be explained by the utilization of polymeric compounds by bacteria, which produce ectoenzymes that could hydrolyze high molecular weight compounds into directly assimilable products.

•E-mail: collinot@ifremer.fr
This exoproteolytic activity is the first main limiting step in the enrichment process of the monomer pool (Halemejko \& Chróst 1986).

The rate of protein utilization could be measured using different methods: uptake of dissolved combined amino acids (DCAA) (Middelboe et al, 1995) and radiolabelled proteins (Hollibaugh \& Azam 1983, Coffin 1989, Keil \& Kirchman 1993) or fluorogenic substrate analogue to a protein, like L-leucine-4-methyl-7coumarinylamide (Leu-MCA) (Hoppe 1983). Although this substrate is not natural, it is susceptible to hydrolysis by bacteria and may serve as a model of the natural protein pool (Hoppe et al. 1988).

At present, Leu-MCA is widely used to study either bacterial nutrition processes or organic matter cycling (Hoppe et al. 1993, Martinez et al. 1996). Exoproteolytic activity is often expressed in term of maximal velocity $\left(V_{\mathrm{m}}\right)$ (Hoppe et al. 1988, Chróst et al. 1989, Chróst 1992, Chróst \& Rai 1993, Gajewski \& Chróst 1995). Such measurement of the potential activity pro- 
vides little information, if any, on the actual rate of protein hydrolysis and uptake by bacteria. However, an in situ activity can be theoretically estimated according to the Michaelis-Menten equation, using both kinetic parameters $\left(V_{\mathrm{m}}\right.$ and Michaelis constant, $\left.K_{\mathrm{m}}\right)$ and DCAA concentration. In fact, this calculation is rarely performed due to the lack of data (Chróst 1992).

The first step of this study was to investigate the significance of exoproteolytic activity $\left(V_{\mathrm{m}}\right)$ in relation to both DCAA pool and bacterial growth rate. The second and main step was to test if the estimates of in situ rates of protein hydrolysis were consistent with bacterial secondary production and therefore provide reasonable estimates of the actual hydrolysis rates.

Our study was performed in a marine Atlantic pond (France). These ponds were characterized by high concentrations of DON (10 to $50 \mu \mathrm{M}_{i}$ Robert et al. 1982) and could support bacterial biomass 10 -fold greater than in the marine environment (Frikha et al. 1987). Since these ponds were shallow, limited in size and had controlled water exchanges, they constituted natural, closed and experimental ecosystems where different mechanisms could be more easily investigated.

\section{MATERIALS AND METHODS}

Sampling procedure. The marine pond studied ( $1 \mathrm{~m}$ deep, $220 \mathrm{~m}^{2}$ ) was located on the Atlantic west coast of France, near La Rochelle $\left(46^{\circ} 12^{\prime} 18^{\prime \prime} \mathrm{N}, 1^{\circ} 11^{\prime} 42^{\prime \prime} \mathrm{W}\right)$. The pond was filled with seawater on March 1, 1994 at high tide. A first batch growth period (28 d) was started at this time. A second period (17 d) was started on March 29, after the pond was half emptied and refilled with new seawater.

Sampling was performed daily during the first $10 \mathrm{~d}$ of each cycle, after which the sampling became less regular. In order to obtain a representative sampling of the pond, water samples were taken daily at 4 sites within the pond and then these 4 subsamples were pooled and immediately transported to the laboratory. Samples for determination of bacterial activity were always processed within $30 \mathrm{~min}$.

Water samples were filtered onto precombusted glass filters $(\mathrm{GF} / \mathrm{F})$ under low pressure $(<50 \mathrm{~mm} \mathrm{Hg}$ ) for chlorophyll a (chl a) concentrations and by gravity for dissolved organic matter and immediately stored frozen until analysis.

Bacteriological biomass and activity. Biomass: Samples for enumeration of bacteria were fixed with a borate buffered formalin ( $2 \%$ final concentration) and cell numbers were counted by epifluorescence microscopy with DAPI staining $(4,6$-diamidino-2phenylindole, final concentration $2.5 \mathrm{mg} \mathrm{l}^{-1}$ ) (Porter \& Feig 1980). Since we noticed a marked change in the
Table 1. Conversion factors used to convert bacterial cell numbers into carbon biomass using mean cell biovolume and

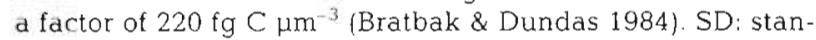
dard deviation

\begin{tabular}{|lcccc|}
\hline $\begin{array}{l}\text { Period of } \\
\text { cycle }\end{array}$ & $\begin{array}{c}\text { Mean cell } \\
\text { volume } \\
\left(\mu \mathrm{m}^{3}\right)\end{array}$ & SD & $\begin{array}{c}\mathrm{n} \\
\text { (cell) }\end{array}$ & $\begin{array}{c}\text { Conversion } \\
\text { factor } \\
\text { (fg C cell-1) }^{-1}\end{array}$ \\
\hline Day 1 to 20 & 0.1296 & 0.065 & 428 & 28 \\
Day 21 to 45 & 0.0488 & 0.009 & 333 & 11 \\
\hline
\end{tabular}

bacteria size, we estimated 2 different conversion factors to convert cell numbers into carbon biomass (Table 1), using mean cell volumes and a factor of $220 \mathrm{fg} \mathrm{C} \mu \mathrm{m}^{-3}$ (Bratbak \& Dundas 1984).

Bacterial secondary production: Bacterial secondary production (BSP) was estimated by the $\left({ }^{3} \mathrm{H}\right.$-methyl)thymidine (TdR) incorporation method (Fuhrman \& Azam 1982). Triplicate samples $(10 \mathrm{ml})$ and a blank (TCA 5\% final concentration added immediately after TdR addition) were incubated with $20 \mathrm{nM}$ (final concentration) of TdR (80.8 $\left.\mathrm{Ci} \mathrm{mmol}^{-1}\right)$ at in situ temperature for $1 \mathrm{~h}$ (Frikha 1989). The rates of TdR incorporation into DNA were converted into cell production using $2.18 \times 10^{18}$ cells produced per mole of thymidine incorporated (Fuhrman \& Azam 1982), after which values were converted into bacterial carbon production using the 2 previous conversion coefficients (Table 1).

Ectoenzyme assay: The exoproteolytic activity (EPA) was determined by using L-leucine-4-methyl7 -coumarinylamide (Leu-MCA) as a protein model substrate. Leucine aminopeptidase activity was the amount of fluorescent 7-amino-4-methylcoumarin (MCA) produced after peptidic bond hydrolysis (Hoppe 1983, Chróst et al. 1989).

For all experiments, $50 \mu \mathrm{l}$ of $0.3,0.6,1.5,2.5,5,10,20$ and $40 \mathrm{mM}$ of Leu-MCA were added to $2 \mathrm{ml}$ of seawater, yielding final concentrations of $7.8,15.6,31.2$, $62.5,125,250,500,1000 \mu \mathrm{M}$. Samples were incubated in the dark at in situ temperature for $1 \mathrm{~h}$. $200 \mu \mathrm{l}$ of sodium-dodecyl-sulfate ( $1 \%$ final concentration) was added to stop the reaction and the samples were immediately frozen (Delmas \& Garet 1995).

Determination of the MCA released was carried out by flow injection analysis using a pump (Kontron, model 414), an injection valve (Beckman, model 210) and a spectrofluorimeter (Kontron, model SFM 25) (Delmas et al. 1994). MCA fluorescence was determined using a borate buffer $(0.1 \mathrm{M}, \mathrm{pH} 10)$. For each sample, duplicates were injected.

Enzyme kinetic data analysis: The kinetic parameters $\left(V_{\mathrm{m}}\right.$ and $\left.K_{\mathrm{m}}\right)$, which referred to substrate analogue added, were calculated from direct plots of reaction velocity versus substrate concentration by nonlinear, 
least-squares regression using Marquardt-Levenberg algorithms to find the minimum sum of squares, with the computer program KINETICS (Brooks 1992). The relative standard deviation for kinetic parameters $V_{\mathrm{m}}$ and $K_{\mathrm{m}}$ was 3.7 and $11.3 \%$, respectively. The turnover time was estimated by the ratio $K_{\mathrm{m}} / V_{\mathrm{m}}$ (Wright \& Hobbie 1966 ).

In our study, knowing both $V_{\mathrm{m}}$ and $K_{\mathrm{m}}$, we could estimate the in situ activity (in $\mu \mathrm{M} \mathrm{d}^{-1}$ ) using Michaelis-Menten equation: $v=\left(V_{\mathrm{m}} \times[\mathrm{S}]\right) /\left(K_{\mathrm{m}}+[\mathrm{S}]\right)$. The substrate concentration ([S]) was the measured ambient DCAA concentration.

Chemical analyses. Dissolved nutrients (nitrate, ammonium) were measured on a Skalar continuous flow analyser according to analytical protocol from Strickland \& Parsons (1972) for nitrate and from Koroleff (1976) for ammonium.

Concentrations of dissolved primary amines (DPA) were determined by flow injection analysis with 0 -phthaldialdehyde using glycine as standard. Concentrations of dissolved free amino acids (DFAA) were estimated after the following correction: DFAA = DPA $\left(\mathrm{NH}_{4} / 32.3\right)$ (Delmas et al. 1990) $\left(\mathrm{NH}_{4}\right.$ results were only used to correct DPA). After hydrolysis $(\mathrm{HCl} 5.8 \mathrm{~N}, 20 \mathrm{~h}$ at $\left.105^{\circ} \mathrm{C}\right)$ and neutralization $(\mathrm{NaOH}$, $2.9 \mathrm{~N})$, the total dissolved amino acids (TDAA) were measured using the same analytical protocol. Concentrations of dissolved combined amino acids (DCAA) were obtained after the subtraction of the DPA: [DCAA] = [TDAA] - [DPA].

After extraction in $100 \%$ methanol at $0^{\circ} \mathrm{C}$ (HolmHansen \& Riemann 1978), chl a concentrations were measured by HPLC. The pigments were separated with a reverse phase column and a methanol/acetone mixture $(75 / 25, \mathrm{v} / \mathrm{v})$ (protocol derived from Mantoura \& Llewellyn 1983) and detected by fluorescence at $430 \mathrm{~nm}$ (excitation) and $663 \mathrm{~nm}$ (emission).

\section{RESULTS AND DISCUSSION}

\section{General environmental background}

After the first filling of the pond, very high nitrate $\left(\mathrm{NO}_{3}\right)$ concentrations $(244 \mu \mathrm{M})$ were present in the water (Fig. 1A); such high nitrogen loads were typical in this area in winter, and they were caused by the enrichment of coastal water by drainage of agricultural areas (Sornin et al. 1990, Delmas et al. 1992). During the first days of the batch period, nitrate decreased as phytoplanktonic biomass increased to its maximum

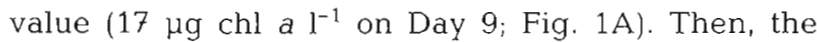
phytoplankton bloom collapsed surprisingly in spite of the level of the nitrate reserve $(100 \mu \mathrm{M})$. At this time and until the next water renewal, nitrate uptake proceeded regularly at a rate of $5.2 \pm 0.4 \mu \mathrm{M} \mathrm{d}^{-1}$ in spite of chlorophyll decrease. In these ponds, in the absence of predation, phytoplankton can theoretically produce $1 \mu \mathrm{g}$ chl a for $1 \mu \mathrm{mol} N$ consumed (Maestrini \& Robert 1981); hence, we might expect that primary production can potentially equal $5 \mu \mathrm{g}$ chl a $\mathrm{d}^{-1}$. This discrepancy between potential chl a production and the ambient chl a values measured in the pond suggests important 


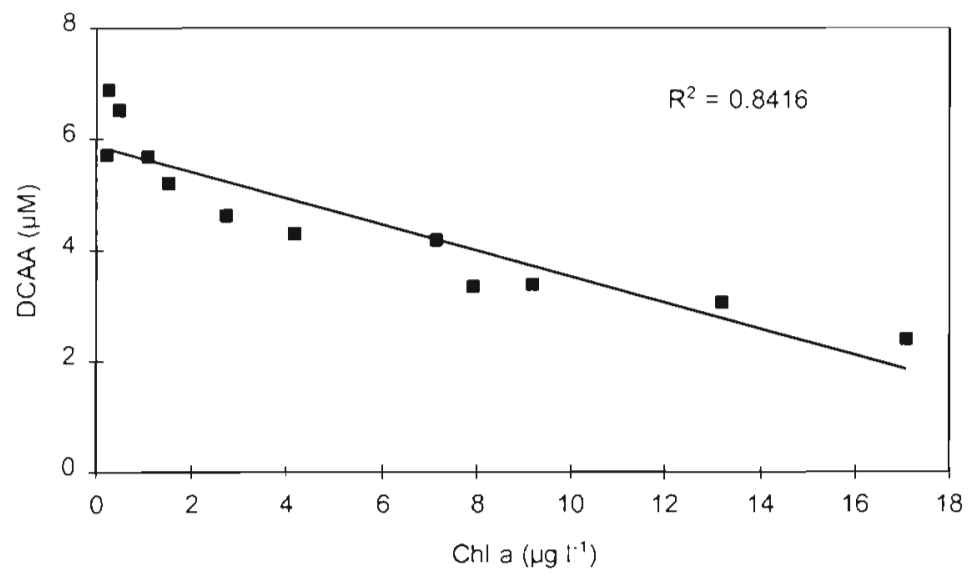

Fig. 2. Relationship between concentration of dissolved combined amino acids (DCAA) and concentration of chlorophyll a (chl a) during the phytoplankton bloom decrease period (Day 9 to 28) compounds (Lampert 1978, Jumars et al. 1989. Chróst 1992). Therefore, this process, which seems to control phytoplankton biomass in the pond, can also explain the increase in DCAA concentrations.

During the first $20 \mathrm{~d}$ of the survey, bacterial numbers increased regularly from $3 \times 10^{9}$ to $30 \times 10^{9}$ cells $^{-1}$, then jumped to $100 \times 10^{9}$ cells $\mathrm{I}^{-1}$ at the end of the first cycle, whereas bacterial abundance remained between 40 and $90 \times$ $10^{9}$ cells $\mathrm{l}^{-1}$ during the second cycle (Fig. 3A). Such abundances and increases have been previously observed in these coastal Atlantic marine ponds (Frikha 1989, Delmas et al. 1992). Concomitant to the evolution of bacterial abundance, high bacterial secondary production (BSP) was recorded. Three maxima of BSP could be observed during the first cycle (Fig. 3B): the first during the bloom of phyto- losses due to predation or cell lysis. In addition, we observed a large bloom of copepods at this time; as zooplanktonic grazing can control phytoplankton biomass (Banse 1992), this process probably explained our observations. After the refilling of the pond, during the second cycle, the nitrate supply content was relatively low $(29 \mu \mathrm{M})$ and the phytoplankton showed only a small increase (maximum $=3.1 \mu \mathrm{g} \mathrm{chl} \mathrm{a} \mathrm{l}^{-1}$ ) (Fig. 1A); then, chl a ranged between 1.1 and $3.4 \mu \mathrm{g} \mathrm{chl} \mathrm{a} \mathrm{l}^{-1}$.

DFAA concentrations averaged $0.34 \mu \mathrm{M}(\mathrm{SD}=0.14, \mathrm{n}=32$ ) and did not show any significant trend of variation, except a short regular increase from 0.23 to $0.94 \mu \mathrm{M}$ between Days 10 and 15, during phytoplankton decrease (Fig, 1B). This lack of large DFAA variation can be explained by rapid cycling of these compounds (Fuhrman 1987. Coffin 1989). In contrast to DFAA, DCAA concentrations increased regularly as the phytoplankton bloom started to collapse and until the next water renewal; after, their concentrations were more or less stable (Fig, 1B). During their rise, between Days 9 and 28, DCAA concentrations negatively correlated to $\mathrm{chl}$ a ( $\mathrm{r}=-0.917, \mathrm{n}=12, \mathrm{p}<0.001 ;$ Fig. 2 ). This indicated a phytoplanktonic origin for these compounds. Zooplankton grazing on phytoplankton is known to be an important source of dissolved
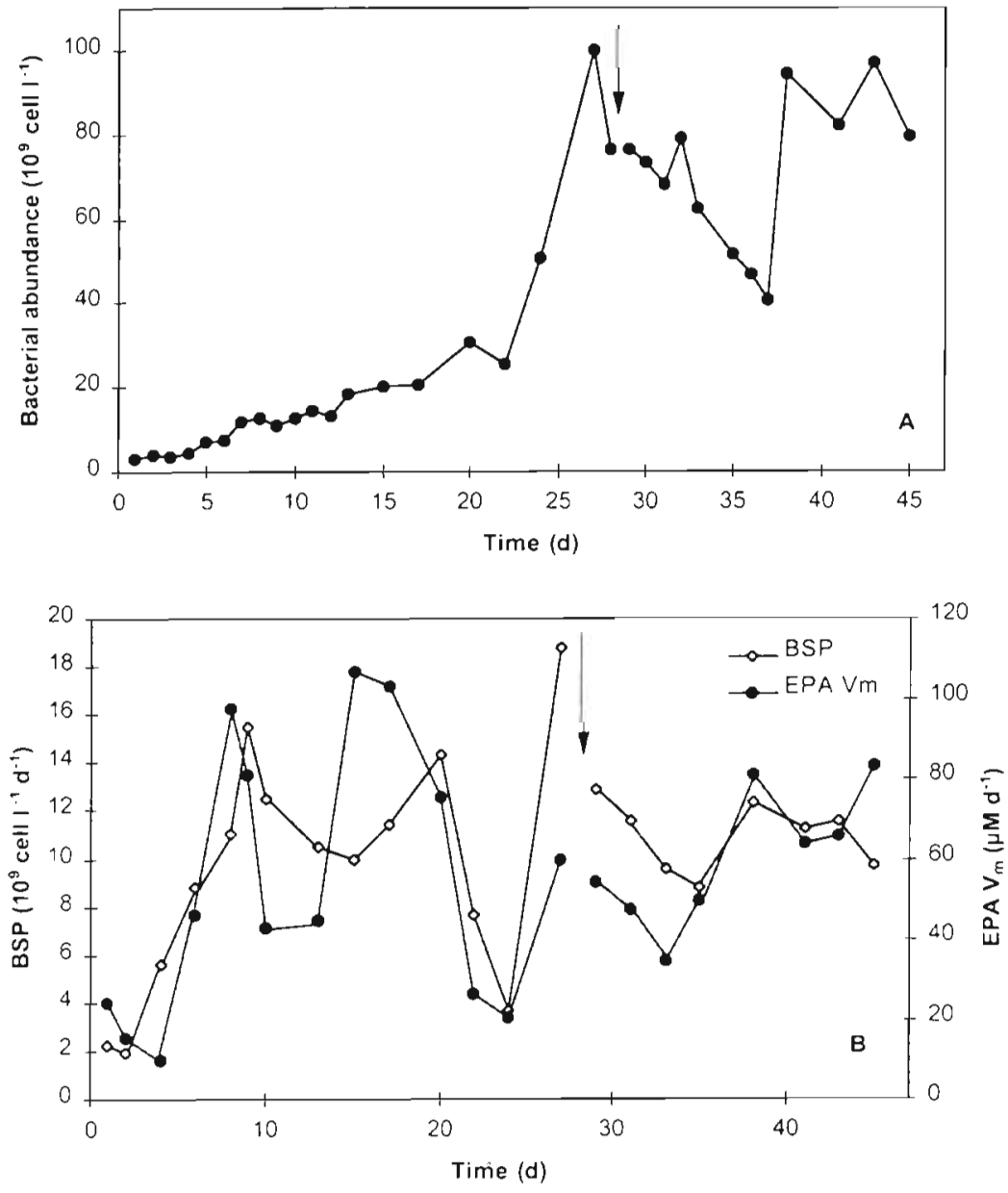

Fig. 3. (A) Bacterial abundance, (B) bacterial secondary production (BSP) and exoproteolytic activity (EPA, $V_{m}$ ) during the 2 cycles. Arrows indicate the refilling of the pond 
Table 2. Exoproteolytic activity parameters during the 2 cycles: maximum velocity $\left(V_{\mathrm{m}}\right)$, Michaelis constant $\left(K_{\mathrm{rm}}\right)$, substrate analogue turnover time (Tn). SD: standard deviation; $\mathrm{n}$ : number of measurements

\begin{tabular}{|lccc|}
\hline & $V_{\mathrm{m}}\left(\mu \mathrm{M} \mathrm{d}^{-1}\right)$ & $K_{\mathrm{m}}(\mu \mathrm{M})$ & $\operatorname{Tn}(\mathrm{d})$ \\
\hline First cycle & & & \\
Mean & 53.7 & 142 & 4.2 \\
SD & 33.8 & 33 & 3.3 \\
$\mathrm{n}$ & 14 & 14 & 14 \\
Min. & 9.7 & 94 & 1.6 \\
Max. & 106.8 & 183 & 10.4 \\
Second cycle & & & \\
Mean & 59.9 & 163 & 2.9 \\
SD & 16.8 & 25 & 0.6 \\
n & 8 & 8 & 8 \\
Min. & 34.6 & 134 & 1.9 \\
Max. & 83 & 219 & 3.9 \\
\hline
\end{tabular}

plankton $\left(15.5 \times 10^{9}\right.$ cells $\left.\mathrm{l}^{-1} \mathrm{~d}^{-1}\right)$, the second during the decrease of chl a $\left(14.3 \times 10^{9}\right.$ cells $\left.\mathrm{l}^{-1} \mathrm{~d}^{-1}\right)$ and the third on the last day of the cycle $\left(18.8 \times 10^{9}\right.$ cells $\left.\mathrm{l}^{-1} \mathrm{~d}^{-1}\right)$ in response to DOM enrichment and its utilization by bacteria. During the second cycle, BSP ranged between 8.8 and $12.9 \times 10^{9}$ cells $1^{-1} \mathrm{~d}^{-1}$.

Maximal velocity of Leu-MCA hydrolysis $\left(V_{\mathrm{m}}\right)$ ranged between 9.6 and $105.6 \mu \mathrm{M} \mathrm{d}^{-1}$ (Fig. 3B, Table 2); these values were higher than generally found in marine waters $\left(3.8 \times 10^{-2}\right.$ to $3.6 \mu \mathrm{M} \mathrm{d}^{-1}$; Hoppe et al. 1988), but similar to the maxima measured in eutrophic freshwaters (4.8 to $120 \mu \mathrm{M} \mathrm{d}^{-1}$; Jacobsen \& Rai 1991). The $V_{\mathrm{m}}$ of protein hydrolysis followed a temporal pattern similar to that of BSP ( $r=0.620, n=22$, $p<0.01$, suggesting that this activity provides significant amounts of readily available substrate for bacterial growth. Hence, mainly during the first cycle, bacterial biomass increased and activity seemed to be related to the DCAA production and zooplankton grazing on phytoplankton.

\section{Estimation of in situ rate of dissolved protein hydrolysis}

In most studies, exoproteolytic activities were addressed in terms of hydrolysation rate (using LeuMCA at tracer concentration) or as kinetic parameters of the Michaelis-Menten equation (Fontigny et al. 1987, Rosso \& Azam 1987, Hoppe et al. 1988, Chróst \& Velimirov 1991, Chróst 1992, Hoppe et al. 1993). Whatever their expression, these results depicted the kinetics of artificial substrate, but not really the kinetics of the dissolved proteins; in addition, these parameters described an average enzymatic kinetic for a complex bacterial community. However, our aim was to esti- mate the actual rate of dissolved protein hydrolysis. Theoretically, knowing the kinetic parameters and the ambient substate concentration, we could calculate an in situ exoproteolysis rate using the Michaelis-Menten equation. For this calculation 2 assumptions were required: (1) the kinetic parameters $V_{\mathrm{m}}$ and $K_{\mathrm{m}}$ of LeuMCA substrate must be representative of natural substrates; (2) DCAA must represent the available dissolved proteins.

Concerning the first assumption, we know that exoproteases display a low specificity (Law 1980, Taylor 1993). Inhibition experiments carried out with proteins such as serum albumin, different peptides and marine indigenous proteins showed a competitive inhibition of Leu-MCA hydrolysis kinetics: there was an increase in apparent $K_{\mathrm{m}}$ but no effect on $V_{\mathrm{m}}$ indicating that the maximal velocity was correctly estimated. Moreover, for marine samples, Billen (1991) obtained the same values of $V_{\mathrm{m}}$ estimated either with fluorogenic substrates or from uptake of labelled proteins. Concerning the $K_{\mathrm{m}}$ obtained by Leu-MCA kinetics, competitive inhibition experiments have shown that proteolytic enzymes exhibit a lower affinity for artificial substrate than for natural proteins and, therefore, the $K_{\mathrm{m}}$ calculated with an artificial substrate is probably an overestimation of the true $K_{\mathrm{m}}$ (Fontigny et al. 1987, Billen 1991). Thus, considering the various uncertainties associated with the estimations of kinetic parameters, we can expect to underestimate the actual in situ dissolved protein hydrolysis rate.

Considering the second assumption, DCAA concentrations measured may not represent only proteins, although these are usually the dominant fraction of DCAA in euphotic waters (Billen 1991). Keil \& Kirchman (1993) found that DCAA measured after acid hydrolysis approximately equalled dissolved protein concentrations obtained with the bicinchoninic acid (BCA) method. However, they showed that a large part of the proteinaceous material was not easily available for bacterial degradation. Abiotic transformation of labile proteins in a refractory state was studied by Keil \& Kirchman (1994); for the protein they tested, the loss of available protein was around $37 \%$ the first day and then this loss rate decrease dramatically with time. In our study, considering the low turnover time estimated for DCAA (mean value $3.7 \mathrm{~d}$, range 1.6 to $10.4 \mathrm{~d}$; Table 2), we can assume that most of these combined amino acids are readily utilizable fresh material. Thus, using DCAA concentrations for the estimation of in situ rate of dissolved protein hydrolysis may not introduce a significant overestimation of the actual hydrolysis rate and probably this overestimation does not compensate for the underestimation due to $K_{\mathrm{m}}$ value.

In the pond, estimated in situ exoenzymatic hydrolysis rates ranged between 0.18 and $3.39 \mu \mathrm{M} \mathrm{d}^{-1}$ and rep- 


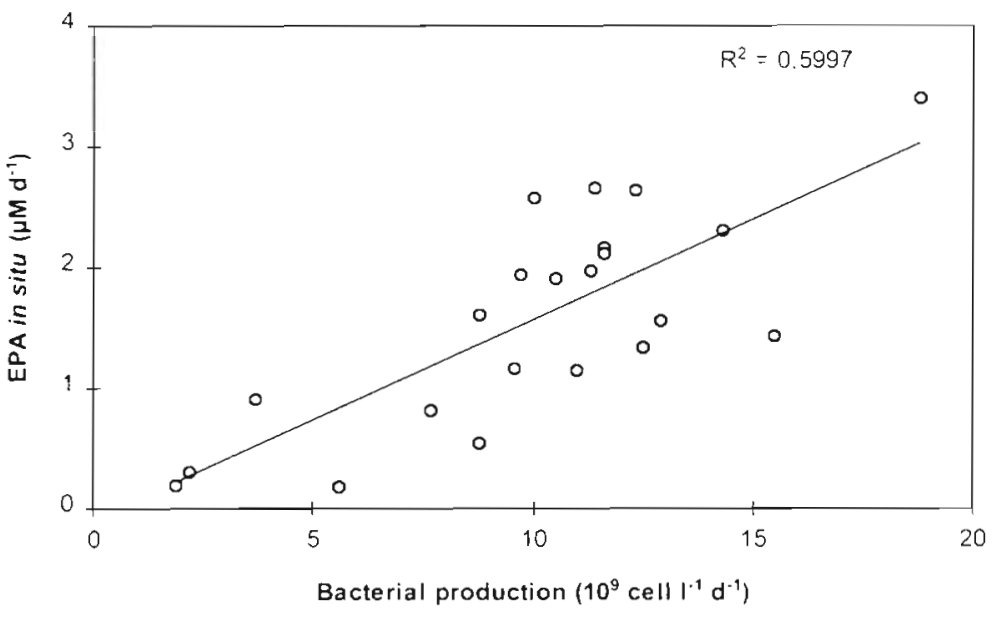

Fig. 4. Relationship between bacterial production and exoproteolytic activity in situ rate (EPA in situ) in pond water

resented only a small fraction of the $V_{\mathrm{m}}$ (between 1.2 and $5.6 \%)$. Although results on dissolved protein degradation were scarce, our estimates were in the range of values measured with labelled proteins in the Delaware estuary (range 1.5 to $3.7 \mu \mathrm{M} \mathrm{d}^{-1}$; Coffin 1989), but they were slightly higher than those obtained from direct DCAA uptake in different ecosystems (range: 0.7 to $1.3 \mu \mathrm{M} \mathrm{d}^{-1}$; Kroer et al. 1994). Middelboe et al. (1995) found that protein hydrolysis, based on Leu-MCA estimates, constituted on average $42 \%$ of the dissolved protein assimilation deduced from direct DCAA measurements. In the pond, the estimated in situ proteolysis showed a temporal evolution close to that of the BSP, increasing regularly during the first cycle, then stabilising during the second. Consequently the estimated in situ rate significantly correlated to BSP $(r=0.774, n=22, p<0.001$; Fig. 4). Therefore, our estimation does not seem unrealistic. The estimated in situ proteolysis represented on average $56 \%$ (range: 6 to $121 \%$ ) of the bacterial nitrogen production, assuming a $\mathrm{C} / \mathrm{N}$ ratio $=4.5$ (Nagata 1986$)$. This result was in the range reported for eutrophic freshwater, estuaries and oceanic waters (between 2 and $112 \%$ of the bacterial nitrogen demand; Keil \& Kirchman 1993, Rosenstock \& Simon 1993, Kroer et al. 1994). Thus, exoproteolytic activity seems to be an important process providing a significant supply of substrates directly available for bacterioplankton from the high DCAA concentration.

In our pond, the flow of nitrogen deduced from dissolved inorganic nitrogen uptake was about $6.2 \mu \mathrm{M} \mathrm{d}^{-1}$ (Fig. 5). On the one hand, the particulate nitrogen protein production by phytoplankton could range between 4.3 and $3.1 \mu \mathrm{M} \mathrm{d}^{-1}$, if we assume that nitrogen proteins represent between 50 and $70 \%$ of the nitrogen uptake (Dortch et al. 1984). As dissolved and par- ticulate organic nitrogen did not accumulate in the pond water (unpubl. results), this flow of nitrogen passed through the food webs and we assumed that it was mostly consumed by zooplankton and became a potential flux of DCAA, available for bacteria. On the other hand, as the net DCAA production (less than $96 \mathrm{nM} \mathrm{d}^{-1}$ ) was insignificant compared to these fluxes, the mean estimated proteolysis in situ rate (1.6 $\mu \mathrm{M} \mathrm{d}^{-1}$ ) could equal the dissolved protein nitrogen production, resulting from algal cell breakage and from the losses caused by sloppy feeding of grazers or from dissolution of faeces. This dissolved protein production may represent between 37 and $50 \%$ of the potential DCAA flux originated from zooplankton grazing, an estimate which is consistent with the results from the literature (Lampert 1978, Riemann et al. 1986, Jumars et al. 1989, Peduzzi \& Herndl 1992). For this approximate nitrogen mass balance, we assumed that nitrogen was processed only once and never regenerated. Despite the above uncertainties, our estimates of in situ proteolysis rate seem realistic, but we cannot affirm that they exactly equal real rates of protein hydrolysis, the main uncertainty being the overestimation of $K_{\mathrm{m}}$ (Table 2). Pantoja et al. (1997)

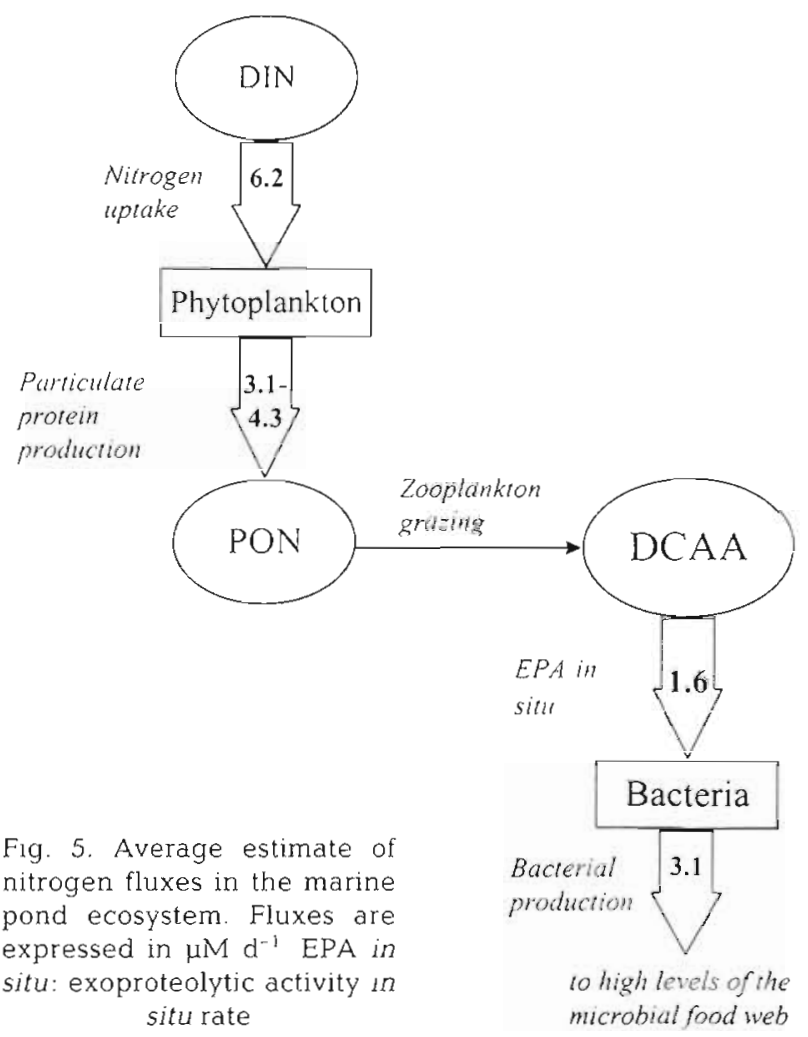


recently found that the $K_{\mathrm{m}}$ for Fluorescent Lucifer Yellow (LYA)-peptides changed significantly according to the size of the peptide; as different exoproteolytic enzymes and different substrates may coexist in natural waters, we can speculate that a broad range of $K_{\mathrm{m}}$ values may exist simultaneously. Using inhibition experiments, Billen (1991) estimated that the $K_{\mathrm{m}}$ of indigeneous peptides ranged between 1.3 and $5.8 \mu \mathrm{M}$ for coastal and estuarine waters. If we used these values to estimate in situ hydrolysis rate, we would obtain results 16 to 150 times greater than those reported above. Such results would not be consistent with our estimated above-mentioned $\mathrm{N}$ balance. Although a broad range of $K_{\mathrm{m}}$ values exists in marine ectoenzymes, our estimates of $K_{\mathrm{m}}$ may be representative of the exoproteases present in several strains of the bacterial community and from the numerous unknown dissolved protein substrates.

\section{CONCLUSION}

In the marine pond under study, bacterial exoproteolytic activity was closely associated with BSP. The high level of exoproteolytic activity recorded was dependent on the flux and accumulation of DCAA. Estimates of in situ proteolysis rates seem to be more representative of the actual rates than $V_{\mathrm{m}}$. Furthermore, these $\mathrm{N}$ fluxes appeared to be coherent with $\mathrm{BSP}$. In this environment, exoproteolytic activity contributes significantly to BSP: we found that approximately half of the total $\mathrm{N}$ uptake went to bacterial production, of which EPA supported about half. The measurement of Leu-MCA hydrolysis has been widely used both in marine and fresh water environments; however, the accuracy of the estimation of the in situ rate may vary from place to place and according to the specific characteristics of the ecosystem. Deviation between the estimated in situ rate of hydrolysis and actual rates probably depends on the availability of dissolved proteins and on the uncertainties of the $K_{\mathrm{m}}$ determinations. Future work to improve our estimation of dissolved proteins should be done as well as calibrations between the kinetics of Leu-MCA hydrolysis and actual dissolved protein breakdown.

Acknowledgements. We thank France Van Wambeke for useful comments on an initial draft of this manuscript and Tom Berman for reviewing the manuscript and for improving the English version.

\section{LITERATURE CITED}

Baines SB, Pace ML (1991) The production of dissolved organic matter by phytoplankton and its importance to bacteria: patterns across marine and freshwater systems.
Limnol Oceanogr 36:1078-1090

Banse K (1992) Grazing, temporal changes of phytoplankton concentrations, and the microbial loop in the open ocean In: Falkowski PG, Woodhead AD (ed) Primary productivity and biogeochemical cycles in the sea. Plenum Press, New York, p 409-440

Billen G (1991) Protein degradation in aquatic environments In: Chróst RJ (ed) Microbial enzymes in aquatic environments. Springer-Verlag, New York, p 123-143

Bratbak G, Dundas I (1984) Bacterial dry matter content and biomass estimations. Appl Environ Microbiol 48:755-757

Brooks SPJ (1992) A simple computer program with statistical tests for the analysis of enzyme kinetics. Biotechniques 13 906-911

Chróst RJ (1990) Microbial ectoenzymes in aquatic environments. In: Overbeck J, Chróst RJ (ed) Aquatic microbial ecology: biochemical and molecular approaches. SpringerVerlag, New York, p 47-78

Chróst RJ (1992) Significance of bacterial ectoenzymes in aquatic environments. Hydrobiologia 243/244:61-70

Chróst RJ, Münster U, Rai H, Albrecht D, Witzel PK, Overbeck J (1989) Photosynthetic production and exoenzymatic degradation of organic matter in the eutrophic lake. J Plankton Res 11:223-242

Chróst RJ, Rai H (1993) Ectoenzyme activity and bacterial secondary production in nutrient-impoverished and nutrient-enriched freshwater mesocosms. Microb Ecol 25 $131-150$

Chróst RJ, Velimirov B (1991) Measurement of enzyme kinetics in water samples: effect of freezing and soluble stabilizer. Mar Ecol Prog Ser 70:93-100

Coffin RB (1989) Bacterial uptake of dissolved free and combined amino acids in estuarine waters. Limnol Oceanogr 34:531-542

Delmas D, Frikha MG, Linley EAS (1990) Dissolved primary amine measurement by flow injection analysis with ophthaldialdehyde: comparison with high-performance liquid chromatography. Mar Chem 29:145-154

Delmas D, Frikha MG, Reymond $\mathrm{H}$, Linley EAS, Collos $\mathrm{Y}$ (1992) Long term microbial community dynamics in a coastal marine pond. Mar Microb Food Webs 6:39-54

Delmas D, Garet MJ (1995) SDS-preservation for deferred measurement of exoproteolytic kinetics in marine samples. J Microbiol Meth 22:243-248

Delmas D, Legrand C, Bechemin C, Collinot C (1994) Exoproteolytic activity determined by flow injection analysis: its potential importance for bacterial growth in coastal marine pond. Aquat Living Res 7:17-24

Dortch Q, Clayton JR, Thorensen SS, Ahmed SI (1984) Species differences in accumulation of nitrogen pools in phytoplankton. Mar Biol 81:237-250

Fontigny A, Billen G, Vives-Rego J (1987) Some kinetic characteristics of exoproteolytic activity in coastal seawater Estuar Coast Shelf Sci 25:127-133

Frikha MG (1989) Ròle des bactéries dans le réseau trophique et les processus de minéralisation d'un marais atlantique de type claire à huîtres. Thèse de doctorat, Université de Bretagne Occidentale, Brest

Frikha MG, Linley EAS, Delmas D (1987) Evolution annuelle et saisonnière de la microbiomasse d'une claire à huîtres: importance des populations bactérioplanctoniques. Océanis 13:433-447

Fuhrman JA (1987) Close coupling between release and uptake of dissolved free amino acids in seawater studied by an isotope dilution approach. Mar Ecol Prog Ser 37 $45-52$

Fuhrman JA, Azam F (1982) Thymidine incorporation as a 
measure of heterotrophic bacterioplankton production in marine surface waters: evaluation and field results. Mar Biol 66:109-120

Gajewski AJ, Chróst RJ (1995) Production and enzymatic decomposition of organic matter by microplankton in a eutrophic lake. J Plankton Res 17:709-728

Halemejko GZ, Chróst RJ (1986) Enzymatic hydrolysis of proteinacenous and dissolved material in a eutrophic lake. Arch Hydrobiol 107:1-21

Hollibaugh JT, Azam F (1983) Microbial degradation of dissolved proteins in seawater. Limnol Oceanogr 28: 1104-1116

Holm-Hansen O, Riemann B (1978) Chlorophyll a determination: improvements in methodology. Oikos 30:438-447

Hoppe HG (1983) Significance of exoenzymatic activities in the ecology of brackish water: measurements by means of methylumbelliferyl-substrates. Mar Ecol prog Ser 11. $299-308$

Hoppe HG, Ducklow H, Karrasch B (1993) Evidence for dependency of bacterial growth on enzymatic hydrolysis of particulate organic matter in the mesopelagic ocean. Mar Ecol Prog Ser 93:277-283

Hoppe HG, Kim SJ, Gocke K (1988) Microbial decomposition in aquatic environments: combined process of extracellular enzyme activity and substrate uptake. Appl Environ Microbiol 54:784-790

Jacobsen TR, Rai H (1991) Aminopeptidase activity in lakes of differing eutrophication. In: Chróst RJ (ed) Microbial enzymes in aquatic environments. Springer-Verlag. New York, p 155-165

Jumars PA, Penry DL, Baross JA, Perry MJ, Frost BW (1989) Closing the microbial loop: dissolved carbon pathway to heterotrophic bacteria from incomplete ingestion, digestion and absorption in animals. Deep-Sea Res 36:483-495

Keil RG, Kirchman DL (1993) Dissolved combined amino acids: chemical form and utilization by marine bacteria. Limnol Oceanogr 38:1256-1270

Keil RG, Kirchman DL (1994) Abiotic transformation of labile protein to refractory protein in sea water. Mar Chem 45: $187-196$

Koroleff F (1976) Determination of ammonia. In: Grasshoff K, Ehrhardt M, Kremling K (eds) Methods of sea water analysis. Verlag Chemie, Weinheim, p 126-133

Kroer N, Jørgensen N, Coffin R (1994) Utilization of dissolved nitrogen by heterotrophic bacterioplankton: a comparison of three ecosystems. Appl Environ Microbiol 60: $4116-4123$

Lampert W (1978) Release of dissolved organic carbon by grazing zooplankton. Limnol Oceanogr 23:831-834

Larsson U, Hagström A (1982) Fractionated phytoplankton primary production, exudate release and bacterial production in a Baltic eutrophication gradient. Mar Biol 67: $57-70$

Law BA (1980) Transport and utilization of proteins by bacteria. In: Payne JW (ed) Microorganisms and nitrogen sources: transport and utilization of amino acids, peptides, proteins, and related substrates. J Wiley \& Sons, Chichester, p 381-409

Maestrini SY, Robert JM (1981) Rendements d'utilisation des sels nutritifs et variations de l'état des cellules de trois diatomées de claires à huîtres de Vendée. Oceanol Acta 4: $13-21$

Mantoura RFC, Llewellyn CA (1983) The rapid determination of algal chlorophyll. and carotenoid pigments and their breakdown products in natural waters by reverse-phase high-performance liquid chromatography. Analyt Chim Acta 151:297-314

Martinez J, Smith DC, Steward GF, Azam F (1996) Variability in ectohydrolytic enzyme activities of pelagic marine bacteria and its significance for substrate processing in the sea. Aquat Microb Ecol 10:223-230

Middelboe M, Borch NH, Kirchman DL (1995) Bacterial utiIization of dissolved free amino acids, dissolved combined amino acids and ammonium in the Delaware Bay estuary: effects of carbon and nitrogen limitation. Mar Ecol Prog Ser 128:109-120

Middelboe M, Sondergaard M, Letarte Y, Borch NH (1995) Attached and free-living bacteria: production and polymer hydrolysis during a Diatom bloom. Microb Ecol 29: $231-248$

Münster U, Chróst RJ (1990) Origin, composition, and microbial utilization of dissolved organic matter. In: Overbeck $J$, Chrost RJ (ed) Aquatic microbial ecology: biochemical and molecular approaches. Springer-Verlag, New York, p $8-46$

Nagata T (1986) Carbon and nitrogen content of natural planktonic bacteria. Appl Environ Microbiol 52:28-32

Pantoja S, Lee C, Marecek JF (1997) Hydrolysis of peptides in seawater and sediment. Mar Chem 57:25-40

Peduzzi P, Herndl GJ (1992) Zooplankton activity fueling the microbial loop: differential growth response of bacteria from oligotrophic and eutrophic waters. Limnol Oceanogr $37: 1087-1092$

Porter KG, Feig YS (1980) The use of DAPI for identifying and counting aquatic microflora. Limnol Oceanogr 25:943-948

Riemann B, Jørgensen N. Lampert W, Fuhrman J (1986) Zooplankton induced changes in dissolved free amino acids and in production rates of freshwater bacteria. Microb Ecol 12:247-258

Robert JM, Maestrini SY, Héral M, Rincé Y, Dreno JP, Beker L (1982) Enrichissement expérimental d'eaux printanières de claires à huitres en baie de Bourgneuf (Vendée, France): augmentation de la biomasse et utilisation des éléments nutritifs par les algues unicellulaires. Hydrobiologia $96: 53-63$

Rosenstock B, Simon M (1993) Use of dissolved combined and free amino acids by planktonic bacteria in Lake Constance. Limnol Oceanogr 38:1521-1531

Rosso AL, Azam F (1987) Proteolytic activity in coastal oceanic waters: depth distribution and relationship to bacterial populations. Mar Ecol Prog Ser 41:231-240

Sharp JH (1983) The distributions of inorganic nitrogen and dissolved and particulate organic nitrogen in the sea. In: Carpenter EJ, Capone DG (ed) Nitrogen in the marine environment. Academic Press, New York, p 1-35

Sornin JM, Collos Y, Delmas D, Feuillet-Girard M, Gouleau D (1990) Nitrogen nutrient transfers in oyster ponds: role of sediment in deferred primary production. Mar Ecol Prog Ser 68:15-22

Strickland JD, Parsons TR (1972) A pratical handbook of seawater analysis. Bull Fish Res Bd Can 167

Taylor A (1993) Aminopeptidases: towards a mechanusm of action. Trends Biochem Sci 18:167-172

Williams PM (1986) Chemistry of dissolved and particulate phases in the water column. In: Eppley W (ed) Plankton dynamics of the Southern California Bight. SpringerVerlag, New York, p 53-83

Wright RT, Hobbie JE (1966) Use of glucose and acetate by bacteria and algae in aquatic ecosystems. Ecology 47 : $447-464$

Submitted: February 14, 1998; Accepted: April 20, 1998

Proofs received from author(s): July 24, 1998 